\title{
Dampak Pengurangan Ketetapan PBB-P2 Terhadap Penerimaan PBB-P2
}

\author{
Amin Setio Lestiningsih, Sabil, Dwiyatmoko Puji Widodo, Ita Depia Siti Rahayu \\ Universitas Bina Sarana Informatika, Indonesia \\ E-mail: amin.asl@bsi.ac.id
}

\begin{abstract}
Abstrak
Pengurangan Ketetapan PBB-P2 merupakan salah satu hak wajib pajak yang dapat diberikan oleh kepala daerah. Untuk pemberian kebijakan pengurangan ketetapan PBB-P2 diatur Peraturan Gubernur( Pergub) yang dapat diberikan kepada masyarakat secara umum dan khusus (Pensiunan, Veteran, dan Purnawirawan). Metode penelitian yang digunakan adalah kuantitatif dengan mengolah data sekunder melalui analisis statistik uji koefisien korelasi, uji koefisien determinasi dan persamaan regresi.Metode pengumpulan data yang digunakan adalah metode observasi, wawancara dan studi dokumentasi.Hasil penelitian menunjukan variabel bebas dan variabel terikat memiliki hubungan yang kuat.Dan hasil uji koefisien determinasi diketahui Pengurangan Ketetapan PBB-P2 berpengaruh signifikan terhadap Penerimaan PBB-P2 sebesar 37\% sedangkan sisanya 63\% dijelaskan oleh faktor-faktor lain yang tidak diteliti. Hasil persamaan regresi linier sederhana adalah $\mathrm{Y}=13,325+0,511 \mathrm{X}$ dengan tingkat signifikan persamaan regresi linier sederhana output Sig (2-Tailed) adalah 0,000 $<0,05$ artinya terdapat persamaan regresi yang signifikan antara Pengurangan Ketetapan PBB-P2 terhadap Penerimaan PBB-P2.
\end{abstract}

Kata kunci: Pengurangan Ketetapan PBB-P2, Penerimaan PBB-P2

\section{Pendahuluan}

Sesuai dengan Peraturan Gubernur Provinsi DKI Jakarta Nomor 211 tahun 2012 tentang Pemberian Pengurangan Pajak Bumi dan Bangunan Perdesaan dan Perkotaan. Hasil penelitian yang dilakukan Lestiningsih dan Adira (2014) disimpulkan bahwa pembayaran PBB belum memberikan peranan yang signifikan terhadap hasil penerimaan Pajak Bumi dan Bangunan terutama pada kelurahan Keagungan yang paling banyak Wajib Pajak menunggak pembayaran PBB hal ini disebabkan karena Wajib Pajak kurang patuh / kurang peduli membayar PBB secara tepat waktu. Sedangkan penelitian yang telah dilakukan oleh Kamaroellah (2017) memberikan hasil bahwa 'tingkat kepatuhan tahun 2014 yaitu 68,52\% (Kurang Patuh) dan tahun 2015 yaitu 79,60 \% (Kurang Patuh) dan tahun 2016 yaitu 81,83 \% (cukup patuh), jadi dapat dikatakan bahwa Wajib Pajak Bumi dan bangunan (PBB) cukup patuh terhadap kewajibannya membayar pajak". Sabil (2017) melakukan penelitian dengan objek Pelayanan Dinas Pendapatan Provinsi Wilayah Kabupaten Bogor dan hasilnya "Pajak Daerah memberikan kontribusi yang cukup tinggi dibandingkan dengan jenis pendapatan yang lainnya”.

\section{Tinjauan Literatur}

\subsection{Pengertian Pajak Bumi Dan Bangunan Perdesaan Dan Perkotaan (PPB-P2)}

Pajak menurut (TMBooks, 2018) Pajak bumi dan bangunan adalah "pajak yang bersifat kebendaan dalam arti besarnya pajak terutang ditentukan oleh keadaan objek yaitu bumi atau tanah dan atau bangunan". 
Menurut Waluyo dan Wirawan dalam (Lestiningsih \& Andira, 2014) mengemukakan bahwa "Pajak Bumi dan Bangunan adalah yang bersifat kebendaan dalam arti besarnya pajak terutang ditentukan oleh keadaan objek pajak yaitu bumi dan bangunan, keadaan subjek (siapa yang membayar) tidak ikut menentukan besarnya jumlah pajak yang terutang".

\subsection{Pengertian Pengurangan Ketetapan PBB-P2}

Pengertian Pengurangan PBB-P2 menurut Peraturan Gubernur No. 211 Tahun 2012 adalah: "Besaran pengurangan PBB-P2 yang terutang dalam Surat Pemberitahuan Pajak Terutang (SPPT) atau Surat Ketetapan Pajak Daerah (SKPD) yang disebabkan oleh kondisi tertentu dari objek yang bersangkutan yang memiliki kaitan dengan penanggung pajak atau bisa juga dengan sebab lainnya atau disebabkan karena adanya musibah bencana alam atau sebab lainnya'.

\subsection{Permohonan Pengurangan PBB-P2}

Pengurangan PBB-P2 pada umumnya dapat dilakukan melalui permohonan secara kolektif, pribadi, maupun badan dengan pemenuhan persyaratan formal dan material yang telah ditentukan. Dasar aturan yang dijadikan pedoman dalam Peraturan Gubernur No. 211 Tahun 2012 adalah "Mentri Keuangan Nomor 110/PMK.03/2009 tentang Pemberian Pengurangan PBB, bahwa besaran pengurangan PBB-P2 dapat diberikan kepada Penanggung Pajak, diantaranya:

1. Memiliki suatu kondisi atas objek pajak yang ada hubungannya dengan penanggung pajak atau sebab lainnya.

2. Keadaan dimana objek pajak yang dimaksud mengalami kejadian luar biasa atau bencana alam".

Kondisi tertentu dari objek yang ada hubungannya dengan penanggung pajak atau karena penyebab tertentu lainnya sebagaimana dimaksud diatas yaitu dapat diberikan untuk objek pajak yang dimiliki oleh Wajib Pajak orang pribadi sebagai berikut:

1. Anggota veteran (pembela dan pejuang kemerdekaan, penerima tanda jasa bintang gerilya, atau janda dudanya)

2. Mantan Presiden dan Wakilnya, mantan Gubernur dan Wakilnya atau janda dudanya

3. Orang pribadi yang memiliki penerimaan hanya dari uang pensiun yang menyebabkan kesulitan dalam pemenuhan kewajiban PBB-P2

4. Orang pribadi yang penghasilannya rendah dan kesulitan dalam melakukan kewajiban PBB-P2

5. Orang pribadi yang penghasilannya rendah, tetapi luas dasar pengenaan pajak atau NJOP per meter perseginya naik karena adanya perubahan lingkungan serta ada efek positif dari pembangunan sarana dan prasarana lainnya.

Pengurangan PBB dapat diartikan bahwa wajib pajak menerima besaran NJOP atas luas tanah dan bangunannya, namun wajib pajak merasa tidak memiliki kemampuan membayar atas kewajiban hutang pajak tersebut. Menurut "pasal 107 ayat (3) Undang-undang No. 28 Tahun 2009 tentang Pajak Daerah Retribusi Daerah (PDRD) pemberian pengurangan diatur oleh Peraturan Kepala Daerah, oleh karena itu Peraturan Gubernur No. 211 Tahun 2012 dibuat guna mengatur persyaratan formal, material yang harus dipenuhi wajib pajak, tata cara pengajuan, besaran jumlah pengurangan serta penyelesaian atas permohonan pengurangan tersebut”.

Dari aturan tersebut jelas bahwa kepala daerah mempunyi kewenangan dan hak untuk memberikan pengurangan.Keputusan besarnya pengurangan yang dapat diberikan tergantung dari hasil analisis kondisi objek pajak yang ada hubungannya dengan subjek pajak.Dapat dikatakan bahwa untuk menentukan besarnya pengurangan yang diberikan oleh fiskus bersifat subjektif, oleh karena itu tidak ada patokan objektif dalam menentukan besarnya pengurangan. Dalam Peraturan Gubernur Provinsi DKI Jakarta No. 211 Tahun 2012 tentang Pemberian Pengurangan PBB-P2 , diatur besarnya pengurangan yang dapat diberikan paling tinggi 50\% dari pajak terutang. Hal ini memberikan kebebasan yang terbatas kepada pengambilan kebijakan untuk memberikan pengurangan asal tidak melebihi $50 \%$ dari pajak terutang.

\subsection{Persyaratan dan besaran pengurangan PBB-P2}


Implementasi pelayanan pengurangan PBB-P2 di Jakarta, pada awal pendaerahan PBB-P2 diatur di Peraturan Gubernur No. 211 Tahun 2012.Pada peraturan gubernur ini segmentasi wajib pajak, masih belum dikelompokan secara spesifik antara wajib pajak yang kalangan masyarakat umum dengan masyarakat veteran dan pensiun PNS, POLRI dan TNI.Peraturan Gubernur diundangkan pada tanggal 28 Desember 2012.Dalam perjalananya dirasa perlu adanya pemberian penghargaan atas jasa dan pengorbanan para Veteran, mantan presiden dan wakilnya, mantan gubernur dan wakilnya, purnawirawan TNI/POLRI, dan pensiunan Pegawai Negeri Sipil (PNS) termasuk janda/dudanya.Kondisi ini menjadi sebuah pertimbangan tersendiri bagi Pemerintah DKI Jakarta khususnya waktu itu Dinas Pelayanan Pajak untuk membuat perturan untuk menghargai jasa para mantan pengabdi negara. Hal tersebut yang menjadi latar belakang untuk pemberian pembebasan sebagian kewajiban dari pembayaran PBB-P2 dengan mengeluarkan Peraturan Gubernur No. 84 tahun 2013 tentang Pembebasan sebagian Pajak Bumi dan Bangunan Perdesaan dan Perkotaan kepada Veteran Pejuang Kemerdekaan,Veteran Pembela Kemerdekaan, Penerima Tanda Jasa Bintang Gerilya, Mantan Presiden dan Manatan Wakil Presiden, Mantan Gubernur dan Mantan Wakil Gubernur, Purnawirawan TNI/POLRI serta Pensiunan Pegawai Negeri Sipil (PNS) janda/dudanya. Yang diundangkan pada tanggal 16 Agustus 2013.

\subsection{Pengertian Penerimaan PBB-P2}

Menurut Undang-undang No. 27 Tahun 2014 "penerimaan perpajakan adalah semua penerimaan negara yang terdiri atas pendapatan pajak dalam negeri dan pendapatan pajak perdagangan internasional".

Menurut Siahaan (2005) dalam (Lestiningsih \& Andira, 2014) "penerimaan Pajak Bumi dan Bangunan adalah penerimaan pajak bumi dan bangunan baik perdesaan maupun perkotaan dan mencangkup semua sektor yang berdiri diatas tanah".

\subsection{Objek PBB-P2}

Menurut Peraturan Daerah No. 16 Tahun 2011 objek PBB-P2 adalah" Bumi dan atau Bangunan yang dimiliki, dikuasai, dan atau dimanfaatkan oleh orang pribadi atau badan, kecuali kawasan yang digunakan untuk kegiatan usaha perkebunan, perhutanan, dan pertambangan. Termasuk dalam pengertian bangunan adalah:

1. Jalan lingkungan yang terletak dalam satu kompleks bangunan seperti hotel, pabrik dan emplasemennya, yang merupakan satu kesatuan dengan kompleks bangunan tersebut

2. Jalan tol

3. Kolam renang

4. Tempat olahraga

5. Galangan kapal, dermaga

6. Taman mewah

7. Tempat penampungan/kilang minyak, air dan gas, pipa minyak

8. Menara

9. Rumah susun

10. Apartemen strata title

\section{Metodologi Penelitian}

Penelitian ini menggunakan pendekatan kuantitatif, yaitu penelitian yang memfokuskan pada pengujian hipotesis, dengan menggunakan data yang dapat diukur untuk mengambil kesimpulan dan yang menjadi objek penelitian adalah UPRD Jatinegara.Populasi dan sampel yang digunakan dalam penelitian ini adalah Pengurangan Ketetapan PBB-P2 dan Penerimaan PBB-P2 tahun 2014 sampai dengan 2018 diambil data dari Delapan (8) Kelurahan yaitu kelurahan Cipinang Besar Selatan, Cipinang Besar Utara, Cipinang Muara, Rawa Bunga, Kampung Melayu, Bidara Cina, Cipinang Cempedak dan Bali Mester selama lima (5) tahun dengan total data 40. Teknik Analisis data menggunakan SPSS untuk uji koefesien 


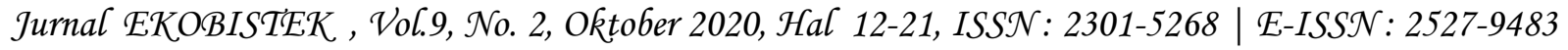
Copyright@2020 by LPPM VPI YPTK Padang

korelasi, dimana variabel $\mathrm{X}_{1}$ adalah pengurangan ketetapan PBB-P2 sedangkan variabel $\mathrm{Y}$ adalah penerimaan PBB-P2

\section{Hasil dan Pembahasan}

\subsection{Data Penelitian}

\subsubsection{Data Variabel X}

Data variabel $\mathrm{X}$ pada penelitian ini terdapat satu variabel bebas yaitu data variabel $\mathrm{X}_{1}$ adalah data pengurangan ketetapan PBB-P2.Berdasarkan data yang diterima penulis dari Unit Pelayanan Pajak dan Retribusi Daerah (UPPRD) Jatinegara Jakarta Timur, jumlah pengurangan ketetapan PBBP2 pada tahun 2014-2018 dapat dilihat pada tabel 1

Tabel 1

Pengurangan Ketetapan PBB-P2 (X)

\begin{tabular}{|c|c|c|c|c|c|}
\hline \multirow{3}{*}{ KELURAHAN } & \multicolumn{5}{|c|}{ VARIABEL $\mathbf{X}$} \\
\hline & \multicolumn{5}{|c|}{ PENGURANGAN KETETAPAN PBB-P2 } \\
\hline & TAHUN 2014 & TAHUN 2015 & TAHUN 2016 & TAHUN 2017 & TAHUN 2018 \\
\hline Bidara Cina & 109.661.609 & 59.895 .725 & 36.054 .345 & 52.067 .538 & 51.706 .545 \\
\hline $\begin{array}{l}\text { Cipinang } \\
\text { Cempedak }\end{array}$ & 250.211 .321 & 262.360 .649 & 176.834 .318 & 187.120 .056 & 279.785 .828 \\
\hline $\begin{array}{l}\text { Cipinang Besar } \\
\text { Selatan }\end{array}$ & 261.404 .725 & 119.117 .727 & 93.235 .942 & 106.009 .445 & 96.537 .347 \\
\hline Cipinang Muara & 157.449 .737 & 200.121 .342 & 165.872 .917 & 153.295 .295 & 246.454 .952 \\
\hline $\begin{array}{l}\text { Cipinang Besar } \\
\text { Utara }\end{array}$ & 63.538 .619 & 23.289 .938 & 19.519 .088 & 14.721 .278 & 17.414 .896 \\
\hline Rawa Bunga & 48.359 .908 & 149.765 .809 & 106.975.662 & 29.718 .892 & 36.158 .915 \\
\hline Balimester & 157.388 .701 & 172.642 .314 & 139.515 .672 & 129.257 .310 & 149.979.016 \\
\hline Kampung Melayu & 47.908 .412 & 122.356 .565 & 84.336 .593 & 26.388 .774 & 28.904 .130 \\
\hline TOTAL & 1.095 .923 .032 & 1.109 .550 .069 & 822.344.537 & 698.578.588 & 906.941.629 \\
\hline
\end{tabular}

Sumber: UPPRD Jatinegara Jakarta Timur

Pada tabel 1 menunjukan data variabel X atau Pengurangan Ketetapan PBB-P2 pada tahun 20142018 mengalami fluktuasi. Pada tahun 2014 pengurangan sebesar Rp 1.095.923.032 tahun 2015 sebesar Rp 1.109.550.069 tahun 2016 sebesar Rp 822.344.537 tahun 2017 sebesar Rp 698.578.588 dan pada tahun 2018 sebesar Rp 906.941.629.

\subsubsection{Data Variabel Y}

Data variabel Y merupakan data penerimaan PBB-P2 yang diterima dari Unit Pelayanan Pajak dan Retribusi Daerah (UPPRD) Jatinegara Jakarta Timur, jumlah Penerimaan PBB-P pada tahun 20142018 dapat dilihat pada tabel 2 
Jurnal EKOBISTEK, Vol.9, No. 2, Oktober 2020, Hal 12-21, ISSN : 2301-5268 | E-ISSN : 2527-9483 Copyright@2020 by LPPM UPI YPTK Padang

Tabel 2

Penerimaan PBB-P2 pada UPPRD Jatinegara Jakarta Timur (Y)

\begin{tabular}{lccccc}
\hline & \multicolumn{5}{c}{ VARIABEL Y } \\
\cline { 2 - 6 } \begin{tabular}{l} 
KELURAH \\
\cline { 2 - 6 }
\end{tabular} & \multicolumn{5}{c}{ PENERIMAAN PBB-P2 } \\
\cline { 2 - 6 } & TAHUN 2014 & TAHUN 2015 & TAHUN 2016 & TAHUN 2017 & TAHUN 2018 \\
\cline { 2 - 6 } Bidara Cina & 11.134 .522 .287 & 11.090 .064 .091 & 12.421 .968 .221 & 12.597 .405 .292 & 15.995 .196 .149 \\
\hline $\begin{array}{l}\text { Cipinang } \\
\text { Cempedak }\end{array}$ & 12.132 .432 .378 & 15.839 .416 .695 & 14.064 .368 .498 & 17.328 .542 .028 & 19.014 .311 .942 \\
\hline $\begin{array}{l}\text { Cipinang } \\
\text { Besar Selatan }\end{array}$ & 5.796 .895 .308 & 11.233 .481 .210 & 12.205 .285 .488 & 10.728 .847 .576 & 11.550 .960 .110 \\
\hline $\begin{array}{l}\text { Cipinang } \\
\text { Muara }\end{array}$ & 7.491 .226 .466 & 9.326 .318 .218 & 8.417 .513 .230 & 8.657 .522 .724 & 11.025 .961 .026 \\
\hline $\begin{array}{l}\text { Cipinang } \\
\text { Besar Utara }\end{array}$ & 2.043 .835 .468 & 2.253 .124 .848 & 1.918 .257 .570 & 1.908 .400 .516 & 2.500 .084 .057 \\
\hline $\begin{array}{l}\text { Rawa Bunga } \\
\text { Balimester }\end{array}$ & 6.070 .867 .653 & 7.685 .305 .649 & 6.610 .569 .021 & 6.897 .439 .446 & 7.612 .914 .888 \\
\hline $\begin{array}{l}\text { Kampung } \\
\text { Melayu }\end{array}$ & 7.404 .350 .069 & 7.774 .225 .319 & 8.259 .809 .152 & 8.696 .408 .614 & 9.940 .896 .839 \\
\hline \multicolumn{1}{c}{ TOTAL } & $\mathbf{5 4 . 1 9 0 . 7 6 7 . 8 1 3}$ & $\mathbf{6 7 . 3 8 9 . 5 6 1 . 9 4 2}$ & $\mathbf{6 6 . 0 1 3 . 2 1 8 . 1 1 1}$ & $\mathbf{6 9 . 3 4 8 . 7 1 5 . 0 2 0}$ & $\mathbf{8 1 . 9 7 8 . 0 0 4 . 6 3 5}$ \\
\hline
\end{tabular}

Sumber: UPPRD Jatinegara Jakarta Timur

Pada Tabel 2 menunjukkan data variabel Y atau Penerimaan PBB-P2 pada UPPRD Jatinegara Jakarta Timur pada tahun 2014-2018 mengalami fluktuasi. Pada tahun 2014 Penerimaan PBB-P2 sebesar Rp 54.190.767.813 tahun 2015 sebesar Rp 67.389.561.942 tahun 2016 sebesar Rp 66.013.218.111 tahun 2017 sebesar Rp 69.348.715.020 dan pada tahun 2018 sebesar Rp 81.978.004.635

Untuk mempermudah penelitian melakukan pengujian dan analisis data maka penulis menyederhanakan data Pengurangan Ketetapan PBB-P2 (X) dan Penerimaan PBB-P2 pada UPPRD Jatinegara Jakarta Timur (Y) dengan menggunakan cara Logaritma Natural (LN) pada Microsoft Excel, dapat dilihat pada tabel 3

Tabel 3

Data Variabel X dan Y yang telah disederhanakan

\begin{tabular}{rccccccccc}
\hline \multicolumn{1}{c}{$\mathbf{X}$} & \multicolumn{1}{c}{$\mathbf{c}$} & \multicolumn{2}{c}{$\mathbf{Y}$} & \\
\hline $\mathbf{2 0 1 4}$ & $\mathbf{2 0 1 5}$ & $\mathbf{2 0 1 6}$ & $\mathbf{2 0 1 7}$ & $\mathbf{2 0 1 8}$ & $\mathbf{2 0 1 4}$ & $\mathbf{2 0 1 5}$ & $\mathbf{2 0 1 6}$ & $\mathbf{2 0 1 7}$ & $\mathbf{2 0 1 8}$ \\
\hline 18,51 & 17,91 & 17,40 & 17,77 & 17,76 & 23,13 & 23,13 & 23,24 & 23,26 & 23,50 \\
\hline 19,34 & 19,39 & 18,99 & 19,05 & 19,45 & 23,22 & 23,49 & 23,37 & 23,58 & 23,67 \\
\hline 19,38 & 18,60 & 18,35 & 18,48 & 18,39 & 22,48 & 23,14 & 23,23 & 23,10 & 23,17 \\
\hline 18,87 & 19,11 & 18,93 & 18,85 & 19,32 & 22,74 & 22,96 & 22,85 & 22,88 & 23,12 \\
\hline 17,97 & 16,96 & 16,79 & 16,50 & 16,67 & 21,44 & 21,54 & 21,37 & 21,37 & 21,64 \\
\hline 17,69 & 18,82 & 18,49 & 17,21 & 17,40 & 22,53 & 22,76 & 22,61 & 22,65 & 22,75 \\
\hline 18,87 & 18,97 & 18,75 & 18,68 & 18,83 & 22,73 & 22,77 & 22,83 & 22,89 & 23,02 \\
\hline 17,68 & 18,62 & 18,25 & 17,09 & 17,18 & 21,47 & 21,51 & 21,47 & 21,65 & 22,19 \\
\hline
\end{tabular}

Sumber: Hasil Olah Penulis 


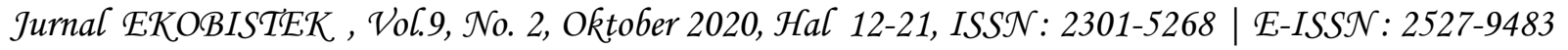
Copyright@2020 by LPPM VPI YPTK Padang

\subsection{Analisis Pengaruh Pengurangan Ketetapan PBB-P2 (X) Terhadap Penerimaan PBB-P2 pada UPPRD Jatinegara Jakarta Timur (Y)}

Pada penelitian ini analisis yang digunakan untuk mengetahui pengaruh variabel bebas (X) terhadap variabel terikat $(\mathrm{Y})$ dengan uji koefisien korelasi yaitu product moment person, uji koefisien determinasi, dan persamaan regresi yaitu uji regresi linier sederhana. Untuk memudahkan peneliti mengolah data penelitian serta menganalisis data tersebeut, peneliti menggunakan program aplikasi IMB SPSS Statistic version 21 .

\subsubsection{Uji koefisien korelasi}

Berdasarkan data yang telah diolah dalam uji koefisien korelasi ini, peneliti menentukan hipotesis sebagai berikut:

$\mathrm{H}_{0}$ : Tidak ada hubungan antara pengurangan ketetapan PBB-P2 terhadap penerimaan PBB-P2 pada UPPRD Jatinegara Jakarta Timur.

$\mathrm{H}_{1}$ : Ada hubungan antara pengurangan ketetapan PBB-P2 terhadap penerimaan PBB-P2 pada UPPRD Jatinegara Jakarta Timur.

Berdasarkan data pengolahan secara manual dan menggunakan SPPS versi 21, maka hasil uji koefisien korelasi dapat dilihat sebagai berikut:

$$
\begin{aligned}
& r=\frac{n \sum X Y-\left(\sum X\right)\left(\sum Y\right)}{=\sqrt{\left.{ }^{n}\left(Z^{2}\right)-\left(\sum X\right)^{2}\right\}\left\{n\left(\sum Y^{2}\right)-\left(\sum Y\right)^{2}\right\}}} \\
& r=\frac{40(16585,5242)-(731,28)(906,4415)}{\sqrt{\left\{40(13396,6763)-(731,28)^{2}\right\}\left\{40(20560,2907)-(906,4415)^{2}\right\}}} \\
& r=\frac{(663420,9693)-(662859,1806)}{\sqrt{\{(535867,052)-(534770,4384)\}\{(822411,6268)-(821636,1929)\}}} \\
& r=\frac{561,7886714}{\sqrt{\{(1096,614)(755,4339)}} \\
& r=\frac{561,7886714}{(33,11516269)(27,8466138)} \\
& r=\frac{561,7886}{992,1451} \\
& r=0,609
\end{aligned}
$$

\begin{tabular}{|c|c|c|c|}
\hline & & $\begin{array}{c}\text { Pengurangan } \\
\text { Ketetapan PBB-P2 }\end{array}$ & Penerimaan PBB-P2 \\
\hline \multirow[b]{3}{*}{ Pengurangan Ketetapan PBB-P2 } & Pearson Correlation & 1 & $609^{* *}$ \\
\hline & Sig. (2-tailed) & & 000 \\
\hline & $\mathrm{N}$ & 40 & 40 \\
\hline \multirow{3}{*}{ Penerimaan PBB-P2 } & Pearson Correlation & $609^{* *}$ & 1 \\
\hline & Sig. (2-tailed) & ,000 & \\
\hline & $\mathrm{N}$ & 40 & 40 \\
\hline
\end{tabular}

Hasil menggunakan IMB SPSS Versi 21 dapat dilihat pada tabel 4

\section{Tabel 4}

\section{Hasil Uji Koefisien Korelasi}

\section{Correlations}

**. Correlation is significant at the 0.01 level (2-tailed).

Sumber: Hasil Pengolahan Data SPSS Versi 21 (2019) 
Untuk mengetahui hubungan yang signifikan antara pengurangan ketetapan PBB-P2 dengan penerimaan PBB-P2, maka dibawah ini terdapat keputusan sebagai berikut:

1. Apabila nilai Sig $<0.05$ maka $\mathrm{H}_{0}$ ditolak, $\mathrm{H}_{1}$ diterima.

2. Apabila nilai Sig $>0.05$ maka $\mathrm{H}_{0}$ diterima, $\mathrm{H}_{1}$ ditolak.

Berdasarkan Tabel 4 dari hasil diatas ditemukan sig (2-tailed) sebesar 0,000 $<0,05$ artinya ada hubungan antara Pengurangan Ketetapan PBB-P2 (X) dengan Penerimaan PBB-P2 (Y). Sehingga $\mathrm{H}_{0}$ ditolak dan $\mathrm{H}_{1}$ diterima.Serta ditemukan Pearson Correlation sebesar 0,609 maka termasuk kategori kuat.

Jadi kesimpulannya terdapat hubungan kuat Pengurangan Ketetapan PBB-P2 (X) terhadap Penerimaan PBB-P2 (Y).

\subsubsection{Uji Koefisien Determinasi}

Uji determinasi digunakan untuk seberapa kuat pengurangan ketetapan PBB-P2 (X) mempengaruhi penerimaan PBB-P2 pada UPPRD Jatinegara Jakarta Timur (Y).peneliti menentukan hipotesis sebagai berikut:

$\mathrm{H}_{0}$ : Tidak ada pengaruh antara pengurangan ketetapan PBB-P2 terhadap penerimaan PBB-P2 pada UPPRD Jatinegara Jakarta Timur.

$\mathrm{H}_{2}$ : Ada pengaruh antara pengurangan ketetapan PBB-P2 terhadap penerimaan PBB-P2 pada UPPRD Jatinegara Jakarta Timur.

Berdasarkan pengolahan data manual dan menggunakan IMB SPPS Versi 21, maka hasil uji koefisien determinasi dapat dilihat sebagai berikut:

$\mathrm{KD}=\mathrm{R}^{2} \mathrm{X} 100 \%$

$\mathrm{KD}=(0,609)^{2} \mathrm{X} 100 \%$

$\mathrm{KD}=37 \%$

Hasil menggunakan IMB SPSS Versi 21 dapat dilihat pada tabel 5

Tabel 5

Hasil Uji Koefisien Determinasi

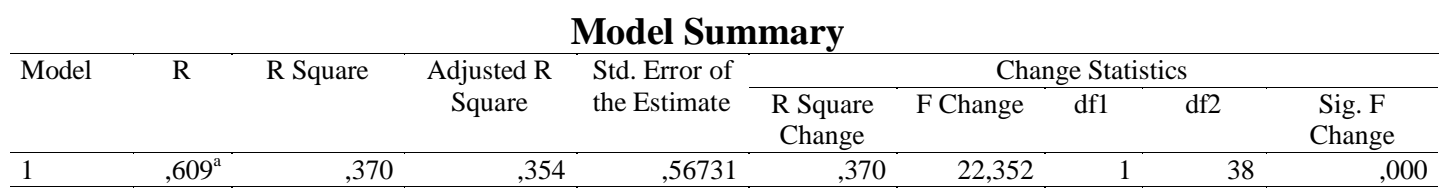

a. Predictors: (Constant), Pengurangan Ketetapan PBB-P2

Sumber: Hasil Pengolahan Data SPSS Versi 21 (2019)

Untuk mengetahui pengaruh yang signifikan antara pengurangan ketetapan PBB-P2 dengan penerimaan PBB-P2, maka dibawah ini terdapat keputusan sebagai berikut:

1. Apabila nilai Sig $<0.05$ maka $\mathrm{H}_{0}$ ditolak, $\mathrm{H}_{2}$ diterima.

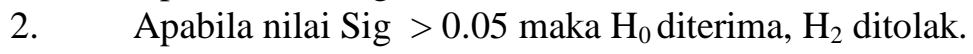

Berdasarkan tabel 5 dari hasil diatas ditemukan $R$ Square Change sebesar $0,000<0,05$ maka $\mathrm{H}_{0}$ ditolak dan $\mathrm{H}_{2}$ diterima. Artinya ada pengaruh antara Pengurangan Ketetapan PBB-P2 (X) terhadap Penerimaan PBB-P2 (Y). Serta ditemukan R Square sebesar 0,370 artinya Pengurangan Ketetapan PBBP2 (X) memiliki pengaruh terhadap Penerimaan PBB-P2 (Y) sebesar 37\% sedangkan 63\% dipengaruhi oleh faktor lain yang tidak diteliti penulis.

\subsubsection{Uji Persamaan Regresi}

Uji persamaan regresi ini befungsi untuk mengetahui persamaan regresi Pengurangan Ketetapan PBB-P2 terhadap Penerimaan PBB-P2.Regresi yang digunakan pada penelitian ini adalah regresi linier 
sederhana. Dalam proses pengolahan data menggunkan secara manual dan program software Statistikal Product \& Service Solutions (SPSS) Version 21. Peneliti menentukan hipotesis sebagai berikut:

$\mathrm{H}_{0}$ : Tidak ada persamaan regresi anatara Pengurangan Ketetapan PBB-P2 terhadap Penerimaan PBB-P2 pada UPPRD Jatinegara Jakarta Timur.

$\mathrm{H}_{3}$ : Ada persamaan regresi antara Pengurangan Ketetapan PBB-P2 terhadap Penerimaan PBB-P2 pada UPPRD Jatinegara Jakarta Timur.

$\mathrm{Y}=\alpha+\mathrm{bX}$

Berikut dapat dilihat hasil dari analisis regresi linier sederhana:

$\mathrm{b}=\frac{\mathrm{n} \sum \mathrm{XY}-\sum \mathrm{X} \sum \mathrm{Y}}{\mathrm{n} \sum \mathrm{X}^{2}-\left(\sum \mathrm{X}\right)^{2}}$

$\alpha=\sum \mathrm{Y}-\mathrm{b} . \sum \mathrm{X}$

$\mathrm{n}$

Berikut perhitungan rumus diatas dari data yang dimiliki:

1. Mencari nilai $b$

$$
\begin{aligned}
& \mathrm{b}=\frac{\mathrm{n} \sum X Y-\sum X \sum Y}{\mathrm{n} \sum \mathrm{X}^{2}-\left(\sum X\right)^{2}} \\
& \mathrm{~b}=\frac{40(16585,5242)-(731,28)(906,4415)}{40(13396,6763)-(731,28)^{2}} \\
& \mathrm{~b}=\frac{663420,968-662859,1806}{535867,052-534770,4384} \\
& \mathrm{~b}=\frac{561,7874}{1096,613} \\
& \mathrm{~b}=0,512
\end{aligned}
$$

\begin{tabular}{|c|c|c|c|c|c|c|}
\hline Model & & Sum of Squares & df & Mean Square & $\mathrm{F}$ & Sig. \\
\hline \multirow{3}{*}{1} & Regression & 7,194 & 1 & 7,194 & 22,352 &, $000^{\mathrm{b}}$ \\
\hline & Residual & 12,230 & 38 &, 322 & & \\
\hline & Total & 19,424 & 39 & & & \\
\hline
\end{tabular}

2. Mencari nilai $\alpha$

$$
\begin{aligned}
& \alpha=\sum_{\mathrm{n}} \mathrm{Y}-\mathrm{b} . \sum \mathrm{X} \\
& \alpha=\frac{(906,4415)-(0,512)(731,28)}{40} \\
& \alpha=\frac{(906,4415)-(374,41536)}{40} \\
& \alpha=\frac{532,02614}{40} \\
& \alpha=13,30065
\end{aligned}
$$

Hasil menggunakan IMB SPSS Versi 21 dapat dilihat pada tabel 6

ANOVA

Tabel 6 ANOVA ${ }^{\mathrm{a}}$

a. Dependent Variable: Penerimaan PBB-P2

b. Predictors: (Constant), Pengurangan Ketetapan PBB-P2 
Jurnal EKOBISTEK, Vol.9, No. 2, Oktober 2020, Hal 12-21, ISSN : 2301-5268 | E-ISSN : 2527-9483 Copyright@2020 by LPPM VPI YPTK Padang

Berdasarkan tabel 6 dapat diketahui nilai signifikan $0,000<0,05$ yang artinya $\mathrm{H}_{0}$ ditolak dan $\mathrm{H}_{3}$ diterima. Kesimpulannya terdapat persamaan regresi antara Pengurangan Ketetapan PBB-P2 terhadap Penerimaan PBB-2. Dibawah ini merupakan tabel hasil uji koefesien regresi:

\begin{tabular}{|c|c|c|c|c|c|c|}
\hline & & $\begin{array}{r}\text { Hasil Uj } \\
\text { Coeffic }\end{array}$ & $\begin{array}{l}\text { [abel } 7 \\
\text { Coefisien } \\
\text { Its }^{\mathrm{a}}\end{array}$ & gresi & & \\
\hline Model & & Unstandardize & Coefficients & $\begin{array}{l}\text { Standardized } \\
\text { Coefficients }\end{array}$ & $\mathrm{T}$ & Sig. \\
\hline & & $\mathrm{B}$ & Std. Error & Beta & & \\
\hline 1 & (Constant) & 13,325 & 1,97 & & 6,741 & ,000 \\
\hline & Pengurangan Ketetapan PBB-P2 &, 511 &, 10 & ,609 & 4,728 &, 000 \\
\hline
\end{tabular}

a. Dependent Variable: Penerimaan PBB-P2

Pada tabel 7 menginformasikan model persamaan regresi yang diperoleh dengan koefisien konstanta dan koefisien varibael yang ada dikolom Unstandardized Coefficients $B$ maka terbentuk model persamaan regresi yaitu $\mathrm{Y}=13,325+0,511 \mathrm{X}$. Artinya jika Pengurangan Ketetapan PBB-P2 (X) sebesar Rp 0 maka Penerimaan PBB-P2 (Y) sebesar Rp 133,25. Sedangkan jika Pengurangan Ketetapan PBB-P2 (X) sebesar Rp 1 maka Penerimaan PBB-P2 (Y) mengalami kenaikan sebesar Rp 511. Koefisien bernilai positif artinya terjadi hubungan positif antara Pengurangan Ketetapan PBB-P2 dengan Penerimaan PBB-P2, semakin meningkat Pengurangan Ketetapan PBB-P2, maka Semakin Menaikan Penerimaan PBB-P2.

\section{Kesimpulan}

Hasil uji koefisien korelasi disimpulkan $\mathrm{H}_{0}$ ditolak dan $\mathrm{H}_{1}$ diterima yang berarti terdapat hubungan yang kuat antara Pengurangan Ketetapan PBB-P2 terhadap Penerimaan PBB-P2.Hasil uji koefisien determinasi disimpulkan adanya pengaruh Pengurangan Ketetapan PBB-P2 (X) terhadap Penerimaan PBB-P2(Y) sebesar 37\% dan 63\% dipengaruhi oleh faktor lain yang tidak diteliti penulis.

\section{Daftar Pustaka}

[1] Dyah, E. (2017). Metode Penelitian Kuantitatif (2nd ed). Yogyakarta: Gava Nedia.

[2] Ghozali. (2016). Aplikasi Analisis Multivariate IBM SPSS. Yogyakarta: Universitas diponegoro.

[3] Kamaroellah, R. Agoes. Analisis Kepatuhan Wajib Pajak Bumi dan Bangunan Berdasarkan Realisasi Penerimaan Pajak Bumi dan Bangunan (PBB) pada Dinas Pendapatan Daerah Kabupaten Pamekasan.Iqtishadia, Jurnal Ekonomi dan Perbankan Syariah, Vol. 4 No. 1 Juni 2017. 102

[4] Lestiningsih, Amin Setio, \& Andira, W. N. (2014). Evaluasi Terhadap Pembayaran Dan Penerimaan Pajak Bumi Dan Bangunan Pada KPP Pratama Jakarta Tamansari Dua. I(1).

[5] TMBooks. (2018). PERPAJAKAN INDONESIA Prinsip dan Praktik (II; A. Diana, ed.). Yogyakarta: CV ANDI OFFSET.

[6 Zulfikar, \& Budianatara, I. N. (2014). Manajemen Riset Pendekatan Komputasi Statistik. Yogyakarta: Deepublish.

[7] Sabil, sabil. (2017). Peranan Penerimaan Pajak Daerah Terhadap Pendapatan Asli Daerah Pada Cabang Pelayanan Dinas Pendapatan Provinsi Wilayah Kabupaten Bogor. Moneter - Jurnal Akuntansi dan Keuangan, 4 (1), 64-72. 
Jurnal EKOBISTEK, Vol.9, No. 2, Oktober 2020, Hal 12-21, ISSN : 2301-5268 | E-ISSN : 2527-9483 Copyright@20206y LPPM VPI YPTK Padang

[8] Peraturan Daerah No. 16 Tahun 2011 tentang Pajak Bumi dan BangunanPerdesaan dan Perkotaan.

[9] Peraturan Gubernur No. 211 Tahun 2012 tentang Pemberian Pengurangan Pajak Bumi dan Bangunan Perdesaan dan Perkotaan

[10] Undang - undang No. 28 Tahun 2009 tentang Pajak Daerah Retribusi Daerah

[11] Peraturan Gubernur No. 84 Tahun 2013 tentang Pembebasan Sebagian Pajak Bumi dan Bangunan Perdesaan dan Perkotaan kepada Veteran Pejuang Kemerdekaan, Veteran Pembela Kemerdekaan, Penerima Tanda Jasa Bintang Gerilya, Mantan Presiden dan Mantan Wakil Presiden, Mantan Gubernur dan Mantan Wakil Gubernur, Purnawirawan TNI/POLRI serta Pensiunan Pegawai Negeri Sipil atau Janda/Dudanya

[12] Surat Keputusan Kepala Dinas Pelayanan Pajak No. 2078 Tahun 2015 tentang Petunjuk Pelaksanaan Pemberian Pembebasan Sebagian Pajak Bumi dan Bangunan Perdesaan dan Perkotaan (PBB-P2)

[13] Undang - undang No. 27 Tahun 2014 tentang Anggaran Pendapatan dan Belanja Negara Tahun Anggaran 2015

[14] Surat Keputusan Kepala Dinas Pelayanan Pajak No. 1101 Tahun 2015 tentang Petunjuk Pelaksanaan Pemberian Pengurangan Pajak Bumi dan Bangunan Perdesaan dan Perkotaan (PBB-P2) 